\title{
ANALYSIS OF POLICY PLANNING DOCUMENTS AND REGULATORY ENACTMENTS FROM THE PERSPECTIVE OF DIGITALIZATION OF HIGHER EDUCATION
}

\author{
R. Strods ${ }^{1}$, L. Daniela ${ }^{1}$, P. Gabriel ${ }^{2}$ \\ ${ }^{1}$ University of Latvia (LATVIA) \\ ${ }^{2}$ University of Avignon (FRANCE)
}

\begin{abstract}
The first fundamental principle of the Magna Charta Universitatum (1988) states that universities are autonomous institutions that produce, examine, appraise and hand down culture through research and teaching. This principle defines universities as autonomous in creating and organizing study programmes and scientific research, among other things, and the laws and regulations of the countries involved in the Bologna Declaration only regulate cooperation between higher education institutions and state institutions in order to harmonize university autonomy with the interests of society and the state. The existing cooperation determined the willingness of the authors of this study to identify the main trends in the development of the digitalization of higher education institutions in normative documents, which were analysed using qualitative data analysis methods such as a graphical organizer and inductive qualitative content analysis. At present, digitalization is rapidly transforming both the physical and social environments and has also exerted significant pressure in the sphere of higher education. Many scholars, including the European University Association (EUA), conclude that digitalization of higher education is a major aspect of development, which should be addressed at a national level to develop appropriate digitalization strategies for all European higher education institutions. This article presents the first results of the cooperative research project OSMOZE between France and Latvia: "The gap between political development documents and real practice of digitalization of higher education".
\end{abstract}

Keywords: Higher education, digitalization, normative documents.

\section{INTRODUCTION}

Nowadays, when national economic development is clearly correlated with the development of smart technologies, externally determined pressure on all of its sectors arises. In other words, technologies are integrated into all sectors of the economy to promote their quality and achieve higher sectorspecific performance indicators, which in general reduces the country's development of global competitiveness. Consequently, the authors of this paper represent education as a national service economy sector with scientific interests related to the integration of technologies into the field of higher education (HE). Researchers in several countries have concluded that there is no longitudinal research that demonstrates the benefits of technology-enhanced learning, whether they are dystopian, such as enhancing the cognitive ability of students, or achieving higher levels of learning outcomes ([1], [2], [3], [4], [5]).

According to the Magna Charta Universitatum (1988) and the Latvian Republic's Law on Institutions of Higher Education, higher education institutions (HEI) in Latvia are autonomous in their activities and responsible for the quality of education. The 1992 Treaty on European Union Education (in this context HE was formally recognized as an area of European Union competence) and Law Article 2e of the Treaty of Lisbon state, however, that the European Union (EU) has competence to carry out activities in the field of education ([6], [7], [8], [9]). Of course, European HEls are autonomous in implementing study content, attracting lecturers, and using finance and other fields; however, there are many laws and regulations at the national and European level governing higher education, and therefore the question of the autonomy of higher education is regularly raised at the community level.

The results of research carried out by the European University Association (EUA) show that only $16 \%$ of $249 \mathrm{HEls}$ from 38 countries have national-level digitalisation strategies for higher education, while $49 \%$ have digitalisation strategies at the HEI level ([10]). The results indicate that the development of digitalisation strategies is consciously needed as it is required more often by the university itself; it also may indicate, however, that the digitalisation of higher education autonomy is an area of competence of the HEl. Studies have shown that a technology-enhanced environment transforms the study 
process and makes it more engaging for students, and through meaningfully integrating technologies, students become more active in their own knowledge construction; therefore, policy discretion and normative documents incorporate a digitalisation discourse on $\mathrm{HE}$ to promote the quality and availability of HE on an international scale ([10], [11], [12]).

The technology pressure on the HE industry, the preservation of university autonomy and the enforcement of political power laws as well as pedagogical innovations in the modern HE space determined the authors' desire to study the tendencies of digitalisation of HE in Latvian and European normative documents.

\section{METHODOLOGY}

To answer the research question: what trends in the digitalisation of higher education can be found in Latvia as a united European higher education area, the authors analysed normative documents using qualitative content analysis ([13]). This method enabled them to obtain a focused and detailed description of the digitalisation of higher education and the classification scheme derived from the analysis that explains this phenomenon. To strengthen their conclusions, the authors also used a quantitative analysis function ([14]). Regulatory enactments, as the sole tool for identifying trends in the digitalisation of higher education, were chosen because, according to the framework of the OSMOZE project, in which this article was developed, the normative enactments should be identified in the first stage of the project. The analysis process consisted of three steps.

In the preparatory phase, the authors identified three groups of documents for analysis: 1. laws, regulations and procedures governing higher education in Latvia; 2. Latvian development and planning documents; 3. legislative documents governing higher education in Europe. Thirty-seven normative documents were analysed, covering 1,089 pages of text. The authors contacted the representative of the Ministry of Education and Science of the Republic of Latvia, Department of Higher Education, Science and Innovation, to identify the most important normative documents governing higher education (see appendix), thus implementing a purposive sample for selecting documents. Individual words, phrases and sentences, reflecting the digitalisation of higher education, were chosen for the analysis units.

Because the authors did not previously study normative documents in the cross-section of HE and wanted to understand the HE digitalisation discourse in the organization phase, they determined inductive analysis was the most appropriate approach to qualitative content analysis. Within the process, progress was made in identifying details (statements on HE digitalisation) and combining them to form categories. Originally the text was encoded by analysing the normative documents using inductive analysis. The notes were written and the phrases on digitalisation of HE were marked using a coding sheet created for the study. Next, similar codes were merged to form subcategories. When determining subcategories, researchers respected the relevant rules for qualitative content analysis, ensuring the categories are internally homogeneous and externally heterogeneous. In turn, the general categories were defined by defining the main categories and generalising them, explaining their characteristics and their relationship with each other.

During the analysis process and the review of the results phase, the authors developed a categorisation generalisation scheme (see Figure 1), explained it and developed criteria that can be used to evaluate and characterise the digitalisation of $\mathrm{HEI}$. 


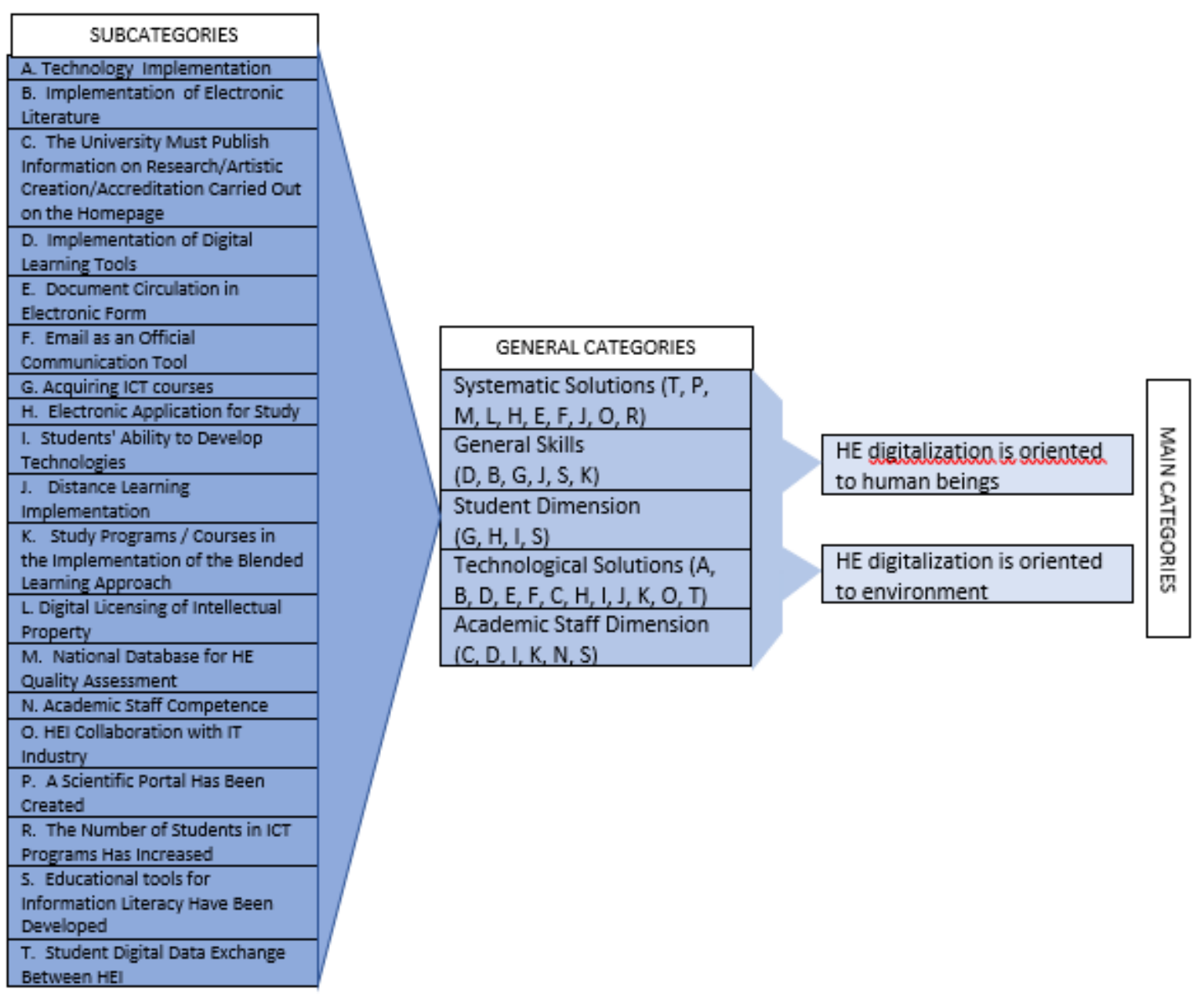

Figure 1. Categorisation Generalisation Scheme

\section{RESULTS}

To answer the research question, the authors analysed the normative documents using an inductive approach to qualitative content analysis. In the process of coding, researchers collectively created 57 codes and, by combining similar ones, they obtained 19 subcategories with categories $A$ to $T$ in the generalisation scheme. To strengthen the results of qualitative content analysis, they also used the frequency quantitative analysis method.

In the normative documents, the idea most often mentioned (10 times) was the need for HE to develop the technological environment; these results were formed by subcategory A. Technology Implementation. This subcategory can be described with the statement in the National Concept of Development of Latvian Higher Education and Higher Education Institutions for 2013-2020 that it is important for the modernization of $\mathrm{HE}$ to implement digital technologies that will change the way of $\mathrm{HE}$ will be delivered ([15]).

The next most commonly used subcategory was found in J. Distance Learning Implementation (7 times). Among the various documents, it was stated that distance learning as a form of study organization will enable HEls to increase the number of students, combat early school leaving, and enrich and improve the learning experience ([16], [17], [18]). The third most commonly identified subcategory was $D$. Implementation of Digital Learning Tools (6 times); it explains that HEls must be designed to incorporate the content needed to implement the curriculum and not just digitise the printed media ([19], [20]).

Most commonly in the normative documents, HE digitalisation is focused on technologies and infrastructure, and only in the fourth most commonly used subcategory is the improvement of the $N$. Academic Staff Competence (5 times) in the context of digitalisation. According to normative documents, lecturers must support the implementation of pedagogical innovations in a student-centred 
study process, as well as to facilitate the opportunity for lecturers to learn and use the potential of digital technologies in the teaching and learning process ([15], [21], [22]).

The authors discovered that only Latvian normative documents require the HEI to organise opportunities for students to acquire various study courses (subcategory $G$.) which would enable them to acquire knowledge in the field of information and communication technologies (ICT) according to their professional requirements ([23], [24], [25]). Subcategory $G$ is closely related to subcategory I because the normative documents provide for students to also be able to create new technological solutions to solve problems within their profession ([26, [26]). In several normative documents, especially in the political space of Latvia, the digitalisation of $\mathrm{HE}$ is more understood as the digitisation of printed media or systems currently operating. This is reflected in the expressions in subcategories $C, E, H, L, M, P$ and $T$. The number of electronic services does not in itself indicate a meaningful digitalisation of $\mathrm{HE}$ - there is a need to analyse service activities to make e-services more convenient than paper-based processes in the past.

By evaluating similar and different subcategories, researchers put forward 5 general categories (the middle column in the Categorisation Generalisation Scheme), which more specifically explain the trends in the digitalisation of HE in normative documents. Analysis of these documents crystallised various general skills necessary for the meaningful implementation of digitalisation of $\mathrm{HE}$, such as media literacy, knowledge of different languages, skills of communication and cooperation, critical thinking, problem solving, entrepreneurship, creativity, problem solving and decision-making skills ([27], [28], [29], [30], [31]). The realisation of general categories like Systemic and Technological Solutions will produce meaningful and qualitative results if the Academic Staff Dimension is seriously accentuated and developed during the digitalisation process of $\mathrm{HE}$, as the academic staff of the universities themselves are innovators and promoters. The Academic Staff Dimension covers various skills and management of different processes; however, the most important should be the implementation of study programs and courses through blended learning to give students experience in using technology to achieve study goals ([32], [17], [20]).

In creating the general categories, researchers defined the answer to the research question as the results clearly showed that there are two trends for the digitalisation of HE: orientation towards human beings and orientation towards a technology-enhanced environment (the column on the right side of Categorisation Generalisation Scheme). The two main categories are not indeterminate among themselves, however; when evaluating normative documents in a retrospective prism, it can be concluded that in earlier documents the digitalisation of $\mathrm{HE}$ focuses on technological and environmental infrastructure changes, while in the latest documents, orientation changes from the environment to the development of human skills in the context of digitalisation.

The authors are convinced that academic staff are the leaders of meaningful HE digitalisation processes, and students must be the main beneficiaries of these changes because digitalisation of $\mathrm{HE}$ is being implemented to improve the study process and achieve the study results necessary for the modern labour market. Therefore, the main orientation in the HE digitalisation process should be toward human beings. In accepting the obtained results, criteria were developed for the evaluation of digitalisation of $\mathrm{HE}$ in the framework of HEI: 1. Involvement of academic staff in the acquisition of pedagogical innovations; 2 . Student and academic staff cooperation for meaningful blended learning implementation; 3. Using technologies as study tools; 4. Academic staff- student-HEl administrationled study process assessment; and 5. Development of new technological solutions in the framework of students' professional activities.

\section{CONCLUSIONS}

Several conclusions can be drawn from a summary of the results. First, the normative documents are dominated by the implementation of technologies and making various services electronic. The digitalisation of the $\mathrm{HE}$ area begins with the implementation of technologies, but at the moment, the development of normative documents should change to emphasise improving people's skills. Second, the normative documents should have a much greater emphasis on students because the main benefit of digitalisation of HE cannot be the reduction of bureaucratic burden or saving of resources but the improvement of the quality of the study process to acquire the competences necessary for a modern labour market and a capable member of modern society. Third, the normative documents should incorporate specific guidelines for the digitalisation of HE as there are only fragmented suggestions that do not contribute to understanding the meaningful digitalisation of HE. Fourth, the normative documents should provide for a system of support and motivation for academic staff to 
learn and implement pedagogical innovations for the meaningful digitalisation of $\mathrm{HE}$ as the main actors of change. In many regulatory documents HE digitalisation is identified as a major development trend in $\mathrm{HE}$, but there is a lack of a purposeful and unified process management system that leads to the conclusion that there should be a unified strategy at national level.

\section{ANNEX}

Policy planning documents and regulatory enactments:

Legislation that regulates higher education in Latvia:

1 Law On Institutions of Higher Education;

2 Law On Scientific Activity;

3 Education Law;

4 Vocational Education Law;

5 The Constitution of the Republic of Latvia;

6 Regulations on the classification of Latvian education;

7 Regulations regarding the State Standard for the Second Level Higher Professional Education;

8 Regulations Regarding Licensing of Study Programmes;

9 Regulations on the State Standard of Academic Education;

10 Regulations Regarding the Requirements, Criteria and Procedures for Admission to Study Programmes;

11 Regulations regarding the State Standard for First Level Professional Higher Education;

12 Regulations for accreditation of higher education institutions, colleges and study fields;

13 Procedures for Financing Institutions of Higher Education and Colleges from the Funds of the State Budget;

14 Procedure for issuing state-recognized certificates of higher education;

15 Mandatory provisions of the study agreement.

Development and planning documents of Latvia:

1 Sustainable Development Strategy of Latvia until 2030

2 National Development Plan of Latvia for 2014-2020

3 Education Development Guidelines for 2014-2020

4 Science, technology development and innovation Guidelines for 2014-2020

5 National Concept of Development of Latvian Higher Education and Higher Education Institutions for 2013-2020

6 The Information Society Development Guidelines for 2014-2020

7 Mass Media Policy Guidelines of Latvia 2016-2020

8 Latvian Memorandum of E-Skills Partnership for 2017-2020

Regulatory enactments that regulates higher education in Europe:

1 Europe 2020, A strategy for smart, sustainable and inclusive growth;

2 Communication from the Commission to the European Parliament, the Council, the European Economic and Social Committee and the Committee of the Regions - Supporting growth and jobs - an agenda for the modernisation of Europe's higher education systems;

3 Communication from the Commission to the European Parliament, the Council, the European Economic and Social Committee and the Committee of the Regions A Digital Agenda for Europe;

4 Sorbonne Declaration 1998;

5 Bologna Declaration 1999; 
6 Prague Communiqué 2001;

7 Berlin Communiqué 2003;

8 Bergen Communiqué 2005;

9 London Communiqué 2007;

10 Leuven Louvain-la-Neuve Communiqué 2009;

11 Budapest-Vienna Declaration 2010;

12 Bucharest Communiqué 2012;

13 Yerevan Communiqué 2015;

14 Paris Communiqué 2018.

\section{ACKNOWLEDGEMENTS}

The article was developed within the framework of co-operation between Latvia and France's Hubert Curien partnership program, "Osmoze" project "The gap between political development documents and real practice of digitalization of higher education" (Registration no. LV-FR 2018/1).

\section{REFERENCES}

[1] L. Daniela, D. Kalnina, R. Strods, "An overview on effectiveness of technology-enhanced learning (TEL)," International Journal of Knowledge Society Research (IJKSR), vol. 8, no. 1, pp. 79-91. 2017. doi:10.4018/IJKSR.2017010105

[2] E. Arenas, "Affordances of Learning technologies in higher education multicultural environments," Electronic Journal Of E-Learning, vol. 13, no. 4, pp. 217-227. 2015.

[3] N. Islam, M. Beer, F. Slack, "E-Learning challenges faced by academics in higher education: A literature review," Journal of Education and Training Studies, vol. 3, no. 5, pp. 102-112. 2015.

[4] L. Nguyen, S. M. Barton, L. T. Nguyen, 'iPads in higher education--hype and hope," British Journal of Educational Technology, vol. 46, no. 1, pp. 190-203. 2015.

[5] D. Lee, A. S. Morrone, G. Siering, "From swimming pool to collaborative learning studio: pedagogy, space, and technology in a large active learning classroom," Educational Technology Research and Development, vol. 66, no. 1, pp. 95-127. 2018.

[6] Magna Charta Universitatum 1998 (IT). Available from: http://www.magna-charta.org/

[7] Law on Institutions of Higher Education (LIHE) 1995 (LV).

[8] Treaty on European Union 1992 (NL). Available from: https://europa.eu/europeanunion/sites/europaeu/.../treaty_on_european_union_en.pdf

[9] Treaty of Lisbon 2007 (PT). Available from: https://eur-lex.europa.eu/legalcontent/EN/TXT/?uri=celex\%3A12007L\%2FTXT

[10] M. Gaebel, V. Kupriyanova, R. Morais, E. Colucci, (ed.), "E-learning in European Higher Education Institutions. Results of a mapping survey conducted in October-December 2013." Retrieved from https://eua.eu/component/attachments/attachments.html?id=414. 2014

[11] A. Hepp, Medienkultur. Die Kultur mediatisierter Welten. Wiesbaden, Germany: Springer Fachmedian, 2011.

[12] L. Daniela, R. Strods, D. Kalnina, "Technology-Enhanced Learning (TEL) in Higher Education Where are we now?" in Knowledge-Intensive Economies and Opportunities for Social, Organizational, and Technological Growth (M. D. Lytras, L. Daniela, A. Visvizi, eds.), pp. 17-31, Hershey, PA: IGI Global, 2018.

[13] S. Elo, H. Kyngas, "The qualitative content analysis process," Journal of Advanced Nursing, vol. 62, no. 1, pp. 107-115. 2008. doi:10.1111/j.1365-2648.2007.04569.x

[14] K. Mārtinsone, A. Pipere, D. Kamerāde, (eds.), Pētniecība: teorija un prakse. Rīga, Latvia: Raka. 2016. 
[15] Latvijas augstākās izglîtības un augstskolu attīstības nacionālā koncepcija 2013-2020. Gadam/National Concept of Development of Latvian Higher Education and Higher Education Institutions for 2013-2020 (NCDLHEHEI) 2013 (LV).

[16] European Commission, Communication from the Commission to the European Parliament, the Council, the European Economic and Social Committee and the Committee of the Regions Supporting growth and jobs - an agenda for the modernisation of Europe's higher education systems 2011 (BE). Available from: https://publications.europa.eu/lv/publication

[17] Sustainable Development Strategy of Latvia until 2030 (SDSL) 2010 (LV). Available from: http://www.varam.gov.Iv/lat/pol/ppd/?doc=13857

[18] Law On Scientific Activity 2005 (LV). Available from: https://likumi.Iv/ta/en/en/id/107337

[19] Education Law 1998 (LV). Available from: https://likumi.lv/ta/en/en/id/50759-education-law

[20] Informācijas sabiedrības attīstības pamatnostādnēm 2014.-2020.gadam/The Information Society Development Guidelines for 2014-2020 (ISDG) 2013 (LV). Available from: http://www.varam.gov.Iv/lat/darbibas_veidi/

[21] Yerevan Communiqué, Ministerial Conference in Yerevan 2015 (AM). Available from: http://www.ehea.info/media.ehea.info/file/2015_Yerevan/

[22] Paris Communiqué, Ministerial Conference in Paris 2018 (FR). Available from: http://www.ehea.info/media.ehea.info/file/2018_Paris/

[23] Noteikumi par otrā līmeña profesionālās augstākās izglitīibas valsts standartu/Regulations Regarding the State Standard for the Second Level Higher Professional Education (RRSSSLHPE) 2014 (LV). Available from: https://likumi.lv/doc.php?id=268761

[24] Regulations Regarding the State Standard for First Level Professional Higher Education (RRSSFLPHE) 2001 (LV). Available from: https://likumi.lv/doc.php?id=6397

[25] Noteikumi par Latvijas izglititibas klasifikāciju/Regulations on the Classification of Latvian Education (RCLE) 2017 (LV). Available from: https://likumi.Iv/doc.php?id=291524

[26] Kārtīiba, kādā izsniedz valsts atzītus augstāko izglïtību apliecinošus dokumentus/Procedure for Issuing State-recognized Certificates of Higher Education (PISRCHE) 2013 (LV). Available from: https://likumi.lv/doc. php?id=256157

[27] Mass Media Policy Guidelines of Latvia 2016-2020 (MMPGL) 2016 (LV) Available from: https://likumi.lv/ta/en/en/id/286455

[28] Latvijas "E-prasmju partnerības" sadarbības memorands 2017.-2020. gadam/Latvian Memorandum of E-Skills Partnership for 2017-2020 (LMESP) 2017 (LV). Available from: http://eprasmes.Iv/wp-content/

[29] Europe 2020, A Strategy for Smart, Sustainable and Inclusive Growth 2010 (BE). Available from: https://publications.europa.eu/lv/publication-detail/

[30] Par Latvijas Nacionālo attīstības plānu 2014.-2020.gadam/About the National Development Plan of Latvia for 2014-2020 (ANDPL) 2012 (LV). Available from: https://likumi.lv/doc.

[31] Par Izglititības attīstības pamatnostādñu 2014.-2020.gadam apstiprināšanu/Approval of the Education Development Guidelines for 2014-2020 (AEDG) 2014 (LV). Available from: https://likumi.lv/doc.php?id=266406

[32] European commission, Communication from the Commission to the European Parliament, the Council, the European Economic and Social Committee and the Committee of the Regions A Digital Agenda for Europe 2010 (BE). Available from: https://publications.europa.eu/ 